\title{
Circulating, but not Local Lung, IL-5 Is Required for the Development of Antigen-induced Airways Eosinophilia
}

\author{
Jun Wang, ${ }^{\star}$ Kay Palmer, ${ }^{\star}$ Jan Lǒtvall, ${ }^{\star}$ Sandra Milan, ${ }^{\star}$ Xue-Feng Lei, ${ }^{*}$ Klaus I. Matthaei, ${ }^{\ddagger}$ Jack Gauldie, ${ }^{\star}$ Mark D. Inman, ${ }^{\star}$ \\ Manel Jordana, ${ }^{*}$ and Zhou Xing ${ }^{*}$ \\ *Immunology and Infection Program, Department of Pathology and Molecular Medicine, McMaster University, Hamilton, Ontario, \\ Canada L8N 3Z5; ${ }^{\ddagger}$ Division of Biochemistry and Molecular Biology, John Curtin School of Medical Research, Australian National \\ University, Canberra ACT 0200, Australia
}

\begin{abstract}
IL-5 is induced locally in the lung and systemically in the circulation during allergic airways eosinophilic inflammation both in humans and experimental animals. However, the precise role of local and systemic IL-5 in the development of allergic airways eosinophilia remains to be elucidated. In our current study, we demonstrate that compared with their IL- $^{+/+}$counterparts, IL-5 ${ }^{-1-}$ mice lacked an IL-5 response both in the lung and peripheral blood, yet they released similar amounts of IL-4, eotaxin, and MIP-1 $\alpha$ in the lung after ovalbumin (OVA) sensitization and challenge. At cellular levels, these mice failed to develop peripheral blood and airways eosinophilia while the responses of lymphocytes, neutrophils, and macrophages remained similar to those in $\mathrm{IL}-5^{+/+}$mice. To dissect the relative role of local and systemic IL-5 in this model, we constructed a gene transfer vector expressing murine IL-5. Intramuscular IL-5 gene transfer to OVA-sensitized $\mathrm{IL}-5^{-1-}$ mice led to raised levels of IL-5 compartmentalized to the circulation and completely reconstituted airways eosinophilia upon OVA challenge, which was associated with reconstitution of eosinophilia in the bone marrow and peripheral blood. Significant airways eosinophilia was observed for at least $7 \mathrm{~d}$ in these mice. In contrast, intranasal IL-5 gene transfer, when rendered to give rise to a significant but compartmentalized level of transgene protein IL-5 in the lung, was unable to reconstitute airways eosinophilia in OVA-sensitized $\mathrm{IL}^{-1-}$ mice upon OVA-challenge, which was associated with a lack of eosinophilic responses in bone marrow and peripheral blood. Our findings thus provide unequivocal evidence that circulating but not local lung IL-5 is critically required for the development of allergic airways eosinophilia. These findings also provide the rationale for developing strategies to target circulating IL-5 and/or its receptors in bone marrow to effectively control asthmatic airways eosinophilia. $(J$. Clin. Invest. 1998. 102:1132-1141.) Key words: IL-5 • eosinophilia • asthma $\bullet$ IL-5 knock-out mice $\bullet$ gene transfer
\end{abstract}

Address correspondence to Zhou Xing, MD, PhD, Rm. 4H19, Health Sciences Centre, Department of Pathology, McMaster University, 1200 Main Street West, Hamilton, Ontario, Canada L8N 3Z5. Phone: 905-525-9140 ext 22471; FAX: 905-522-6750; E-mail: xingz@fhs.csu. mcmaster.ca

Received for publication 17 April 1998 and accepted in revised form 17 July 1998

J. Clin. Invest.

(C) The American Society for Clinical Investigation, Inc. 0021-9738/98/09/1132/10 \$2.00

Volume 102, Number 6, September 1998, 1132-1141

http://www.jci.org

\section{Introduction}

Airways eosinophilic inflammation is a central pathologic feature of allergic asthma. The severity of asthma is correlated with the degree of airways eosinophilia $(1,2)$. Eosinophils contribute to the pathogenesis of asthma by releasing a number of inflammatory mediators and toxic products including oxygen radicals and cationic proteins that can severely damage the airway epithelium and increase airway reactivity $(1,2)$. Thus, understanding the molecular mechanisms underlying allergic airways eosinophilia has been a subject of intensive investigation. Eosinophils, like other types of leukocytes, originate from myeloid precursors in the bone marrow, but different from others, they are not present in abundance in the peripheral blood under resting conditions. It is believed that during immuneinflammatory responses, in addition to local tissue signals, a systemic signal(s) capable of eosinophil mobilization in the bone marrow is also required for the development of allergic airways eosinophilia. Among many soluble signals, IL-5 is considered to play an important role in the genesis of airways eosinophilia (1-4). Indeed, this cytokine has been found at raised levels both in the peripheral blood and lung tissue compartments in asthmatic patients (5-8). Similar findings were obtained from experimental models of allergic asthma where the peak circulating level of IL-5 preceded that in the lung after aerosol antigen challenge $(9,10)$, suggesting the presence of antigen-specific lymphocytes both within and outside the respiratory mucosa. IL-5 is a well recognized eosinopoietic growth factor capable of stimulating eosinophil differentiation and maturation both in vitro and in vivo (2, 3, 11-13). Furthermore, IL-5 has also been shown to be an eosinophil chemoattractant and a potent eosinophil survival enhancer (14-17). By using transgene approaches, we and others have shown that overexpression of IL-5 locally in the lung, as opposed to systemic overexpression (18), induces marked airways eosinophilia $(19,20)$ or reconstitutes antigen-induced airways eosinophilia in IL- $5^{-1-}$ mice (21), and such induction of airways eosinophilia is always associated with systemic leakage of IL-5 and peripheral blood eosinophilia (19-21). On the other hand, systemic administration of anti-IL-5 monoclonal antibodies, which abrogates both local and systemic IL-5, has been shown to inhibit antigen-induced airways eosinophilia in experimental models (22-24). While these findings support an important role of IL-5 in the pathogenesis of allergic airways eosinophilia, the precise functional role of local and systemic IL-5 remains to be dissected.

In our current study, we have used two transgenic tools, IL-5 gene-deficient mice and an IL-5 gene transfer vector, to investigate the role of local and circulating IL-5 in the development of antigen-induced airways eosinophilia. Combined use of these genetic tools allowed us to reveal that circulating but not local lung IL-5 is critically required, via its effects on bone 
marrow and peripheral blood eosinophils, for the development of antigen-induced airways eosinophilia. Our findings suggest that circulating but not local IL-5 or its receptors in bone marrow represent a single, straightforward target for therapeutic strategies designed to effectively control asthmatic airways eosinophilia.

\section{Methods}

Mice and antigen-induced allergic airways inflammation. The generation and characterization of C57BL/6 IL-5 gene knock-out (IL-5 ${ }^{-1-}$ ) and littermate control mice (IL-5 $5^{+/+}$) have been described elsewhere (12). Male or female mice were bred and maintained in the Level B pathogen-free facility at McMaster University Animal Quarter. Mice at the age of 8-12 wk were used. A mouse model of antigen-induced allergic airways inflammation was set up by ovalbumin (OVA) ${ }^{1}$ sensitization and challenge as previously described by us (10). In brief, mice were intraperitoneally sensitized twice, $5 \mathrm{~d}$ apart (day -17 and day -12) with $0.5 \mathrm{ml}$ of a solution containing $8 \mu \mathrm{g}$ OVA (Sigma Chemical Co., St. Louis, MO) adsorbed overnight at $4^{\circ} \mathrm{C}$ to $4 \mathrm{mg}$ of aluminum hydroxide (Aldrich Chemical Company, Inc., Milwaukee, WI) in PBS (Fig. 1). Mice were then challenged at $12 \mathrm{~d}$ after the second sensitization with aerosolized OVA (day 0) (Fig. 1).

Construction and preparation of recombinant replication-deficient adenoviral vector expressing $m I L-5$. A 600-bp EcoRI/HindIII fragment of full-length murine IL-5 cDNA was isolated from pEDFM-16 (a kind gift from Dr. Alistair Ramsay, Australian National University, Canberra, Australia) and ligated into the multicloning site of the shuttle vector pACCMV. The resultant pACCMV mIL-5 contained the mIL-5 cDNA positioned between a human cytomegalovirus promoter (CMV) and a SV40 splicing junction/polyA signal (polyA) in an orientation that allowed for the transcription of mIL-5 cDNA under control of the CMV promoter (Fig. 2). This plasmid was cotransfected into 293 cells along with a plasmid pJM17, which contained the entire Ad5 DNA sequences with an insert in the E1 region (25). By homologous recombination, the recombinant replication-deficient adenovirus Ad5E1pACCMVmIL-5 (AdIL-5) was rescued (Fig. 2). AdIL-5 was characterized by Southern and Northern hybridizations. The production of IL-5 was determined by ELISA with the supernatant of A549 cells infected by AdIL-5 in vitro. Viral vectors were purified, titered, and stored as previously described (26). A control viral vector Addl70-3 containing no transgene was used throughout the entire study.

Intramuscular or intranasal IL-5 gene transfer by AdIL-5. Mice were injected intramuscularly (i.m.) with AdIL-5 or Addl70-3 at $5 \mathrm{~d}$ before OVA challenge following a procedure we have previously described (27). This approach was shown to result in marked transgene expression only in the muscle at the site of injection and active release of transgene protein into the circulation (27). A dose of $0.1 \times 10^{9} \mathrm{pfu}$ of vector was diluted in a total of $100 \mu \mathrm{l}$ of PBS and injected i.m. into two hind legs of mice (two injection sites per leg, $25 \mu$ l per site). In separate experiments, intranasal administration (i.n.) was performed to deliver transgene into the lung at $3 \mathrm{~d}$ before OVA challenge following a procedure we have previously described (28). We have previously demonstrated that this approach targets the transgene primarily to the bronchial epithelial cells and, to a lesser degree, to the alveolar epithelial cells and macrophages (28). A dose of $0.12 \times 10^{9} \mathrm{pfu}$ of vector was diluted in a total $30 \mu \mathrm{l}$ of PBS and delivered i.n. into appropriately anesthetized mice with a fine pipette tip (two administrations, $15 \mu$ l each).

1. Abbreviations used in this paper: $\mathrm{BAL}$, bronchoalveolar lavage; $\mathrm{CMV}$, cytomegalovirus promoter; i.m., intramuscularly; i.n., intranasally; OVA, ovalbumin.
OVA challenge by aerosolization

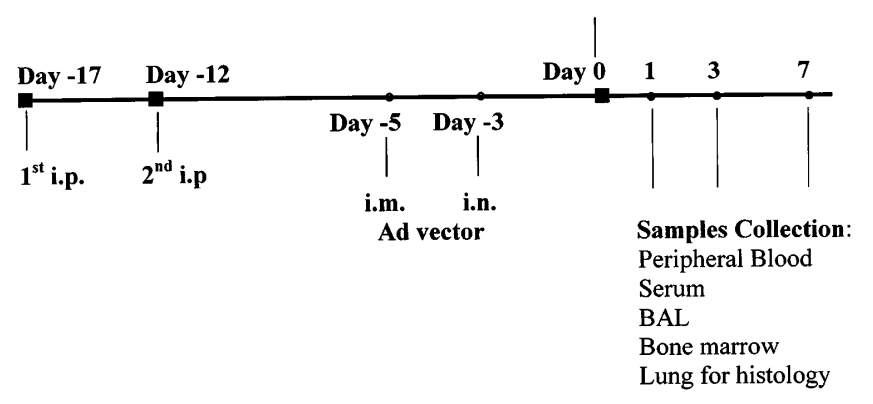

Figure 1. The mouse model of antigen-induced allergic airways inflammation. IL- $5^{-/-}$and IL-5 $5^{+/+}$mice were sensitized twice intraperitoneally (i.p.) with $0.5 \mathrm{ml}$ of aluminum OVA at days -17 and -12 , then challenged by aerosolized OVA at day 0 . The level of cellular responses in the lung, peripheral blood, and bone marrow and cytokine profiles were determined at days 1,3 , and 7, respectively. In separate experiments, OVA-sensitized IL- $5^{-1-}$ mice were subjected to i.m. or i.n. delivery of AdIL-5 or Addl70-3 at days 5 and 3 before OVA challenge, respectively.

Preparation of blood smear, serum, bronchoalveolar lavage fluid and lung tissue. The mice were sacrificed at days 1,3, or 7 after OVA challenge, and the peripheral blood, bronchoalveolar lavage (BAL), lung, and bone marrow were collected. Blood samples were obtained by retro-orbital bleeding. Total white blood cell numbers were determined after red blood cells lysis with RBC lysis buffer, and peripheral blood smears were prepared in duplicate with heparinized blood samples. Differential cell types were determined on blood smears by randomly counting 300-500 leukocytes. Serum was prepared from the whole blood by centrifugation at $12,000 \mathrm{rpm}$ in a microcentrifuge for $10 \mathrm{~min}$ at $4^{\circ} \mathrm{C}$ after incubation at $37^{\circ} \mathrm{C}$ for $30 \mathrm{~min}$ and stored at $-20^{\circ} \mathrm{C}$ until cytokine assays. BAL was performed as previously described $(10,28)$. The mouse lung was lavaged with a total of $450 \mu \mathrm{l}$ of PBS in two separate aliquots $(250 \mu \mathrm{l}$ and $200 \mu \mathrm{l})$ through a polyethylene tube (Becton Dickinson, Sparks, MD) cannulated into the mouse trachea. Approximately $350 \mu \mathrm{l}$ of BAL was recovered by gentle massage of the lungs while retrieving. BAL fluids were then spun in a microcentrifuge at 5,000 rpm for $5 \mathrm{~min}$, and supernatants were stored in $-20^{\circ} \mathrm{C}$ until cytokine measurements. Cell pellets were resuspended in PBS and total cell numbers counted on a hemocytometer. Cytospins were prepared by cyto-centrifugation (Shandon Inc., Pittsburgh, PA). Differential cell counts were determined on Diff-Quik-stained (Baxter, McGaw Park, IL) cytospins by randomly counting $\sim 400$ cells per slide. The lung was fixed by perfusion with $10 \%$ formalin. Lung sections were stained with hematoxylin and eosin.

Preparation of bone marrow cells. The femur was surgically removed and the connective tissues were carefully scraped off the bone. Both ends of the femur were opened using a sharp scalpel, and the marrow was perfused by repeatedly injecting $1.5 \mathrm{ml}$ of $5 \mathrm{~A}$ culture medium from the distal end of the femur, using a 3-ml syringe and a $23 \mathrm{G}$ needle. Bone marrow cells were dispersed by repeatedly moving the perfusate with bone marrow fragments in and out of the syringe, through the needle. Cytospins of dispersed bone marrow cells were prepared on APTEX coated glass slides. The slides were fixed using Diff-Quik fixative (Dade Diagnostics of P.R. Inc., Aguada, Puerto Rico), and stained using standard eosin staining techniques. The number of mature eosinophils was estimated by differential counting of 500-2,000 cells under a microscope with oil immersion.

Cytokine and IgE measurements. Murine IL-5 was measured by using an ELISA kit (Amersham, Buckinghamshire, UK). Murine IL-4, MIP- $1 \alpha$, and eotaxin were measured by using ELISA kits purchased from R\&D Systems (Minneapolis, MN). The sensitivity of detection of these ELISA kits was $5 \mathrm{pg} / \mathrm{ml}$ for IL-5 and 2 to $3 \mathrm{pg} / \mathrm{ml}$ for IL-4, eotaxin, and MIP-1 $\alpha$. The level of OVA-specific IgE in serum was de- 


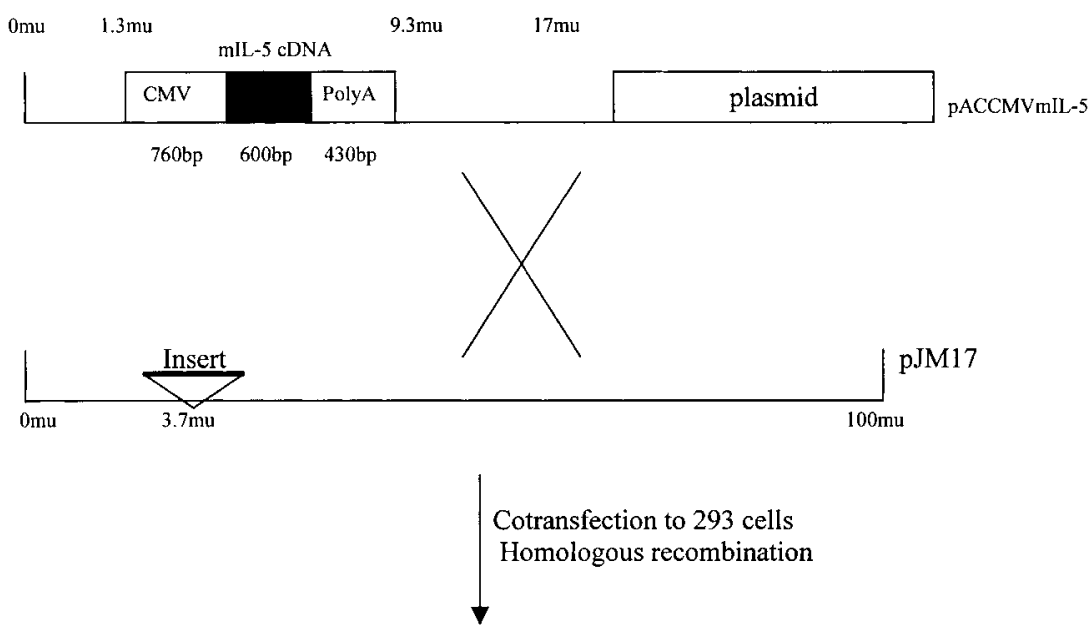

Figure 2. Construction of recombinant adenovirus Ad5E1pCCMVmIL-5 (AdIL-5) expressing murine IL-5. The plasmid pACCMVmIL-5 was constructed by inserting murine IL-5 cDNA into a shuttle vector pACCMV, which carried a CMV and an SV40 splicing junction/polyA signal (poly $A)$. The recombinant adenovirus AdIL-5 was rescued by homologous recombination after cotransfecting 293 cells with pACCMVmIL-5 and a virus-rescuing vector $\mathrm{pJM} 17$.

termined by using an antigen-capture ELISA method as previously described (10)

Data analysis. Wherever applicable, results and differences were statistically analyzed by using a Minitab statistical software package (Minitab; State College, PA). An unpaired $t$ test was used and the difference was considered statistically significant when $P \leq 0.05$.

\section{Results}

Lack of antigen-induced airways and peripheral blood eosinophilia in IL-5 $5^{-1}$ mice. We characterized the difference in airways inflammation and peripheral blood responses between C57BL/6 IL-5 $5^{-/-}$and littermate control IL- $5^{+/+}$mice. OVA sensitization and aerosol challenge were carried out in these mice as previously described (10) (Fig. 1). Samples were collected and analyzed at days 1 and 3 after OVA challenge. We have previously demonstrated that cytokine and cellular responses peaked at days 1 and 3 in mice $(10,29)$. The resting numbers of pulmonary macrophages in BAL fluids of naive IL- $5^{+/+}$and IL- $5^{-/-}$mice were similar (Fig. 3). However, OVA challenge induced an approximately fivefold increase in total cell number in BAL from sensitized IL- $5^{+/+}$mice and only a threefold increase in sensitized IL- $5^{-1-}$ mice at day 3. Approximately $50 \%$ of these cells in IL- $5^{+/+}$mouse lung were eosinophils. In contrast, there was only a marginally increased number of eosinophils found in BAL from IL- $5^{-1-}$ mice (Fig. 3). Of note, the number of lymphocytes, neutrophils, and macrophages increased to a similar degree in both $\mathrm{IL}-5^{-/-}$and IL- $5^{+/+}$mice. We then examined the inflammatory response in the peripheral blood. An increased level of peripheral blood eosinophilia in IL-5 $5^{+/+}$mice was observed after second OVA sensitization that further increased after OVA challenge (Table I). In contrast, there was a lack of peripheral blood eosinophilia in IL- $5^{-1-}$ mice, thus in keeping with a lack of airways eosinophilia. The numbers of other cell types were comparable between $\mathrm{IL}-5^{+/+}$and IL- $5^{-/-}$mice. While not surprisingly, there was no measurable IL-5 in BAL and serum from IL- $5^{-1-}$ mice, and $\sim 260$ and $390 \mathrm{pg} / \mathrm{ml}$ of IL-5 were detected in serum and BAL collected from IL-5 $5^{+/+}$mice at day 1 after OVA challenge, respectively (Fig. 4).
Characterization of an adenoviral gene transfer vector expressing murine IL-5. Having demonstrated a lack of IL-5 and eosinophilia in the peripheral blood and airways in OVA-sensitized IL- $5^{-/-}$but not IL- $5^{+/+}$mice upon antigen challenge, we set out to investigate the relative contribution of local and circulating IL-5 to the development of airways eosinophilia. A transgene approach was chosen to achieve IL-5 levels in a selected compartment in IL- $5^{-1-}$ mice. This approach, in contrast to the use of recombinant protein, would allow us to achieve transient but prolonged levels of IL-5 in vivo (30). To this end, a recombinant replication-deficient adenoviral gene transfer vector expressing murine IL-5 transgene was constructed (AdIL-5; Fig. 2). AdIL-5 was characterized by HindIII restriction digestion and Southern and Northern hybridization (data not shown). Upon infection with $10 \mathrm{pfu} / \mathrm{cell}$ of AdIL-5 but not with Addl70-3, A549 cells released $40.46 \mathrm{ng} / \mathrm{ml}$ of IL-5 in $48 \mathrm{~h}$ in vitro. To characterize AdIL-5 in vivo, four different doses of

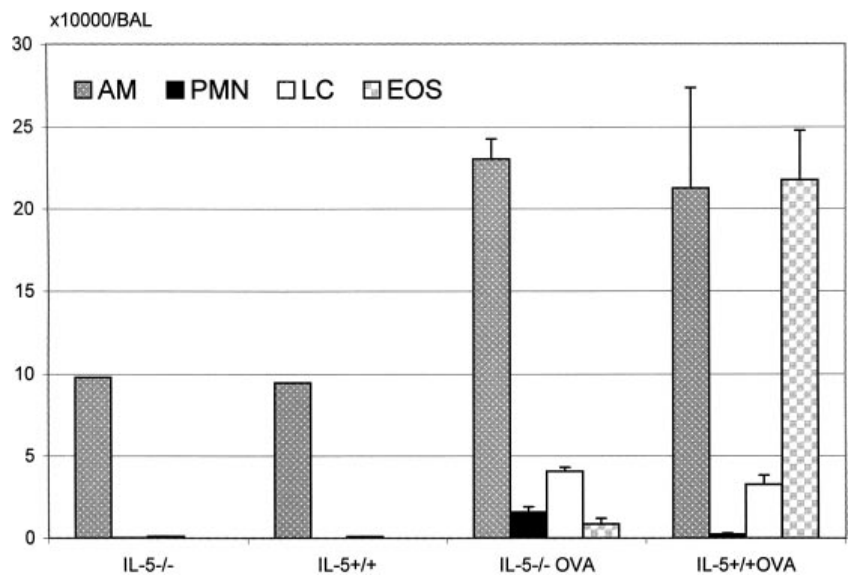

Figure 3. Comparison of cellular responses in the BAL between IL$5^{-/-}$and IL-5 $5^{+/+}$mice. BAL fluids were collected from untreated naive mice $\left(n=2\right.$ each) or from OVA-sensitized and challenged IL- $5^{-/-}$ $(n=3)$ and ${\mathrm{IL}-5^{+/+}}_{(}(n=5)$ mice $(3 \mathrm{~d})$ and cellular responses were determined by cell differential counting. Data represent mean \pm SEM. 


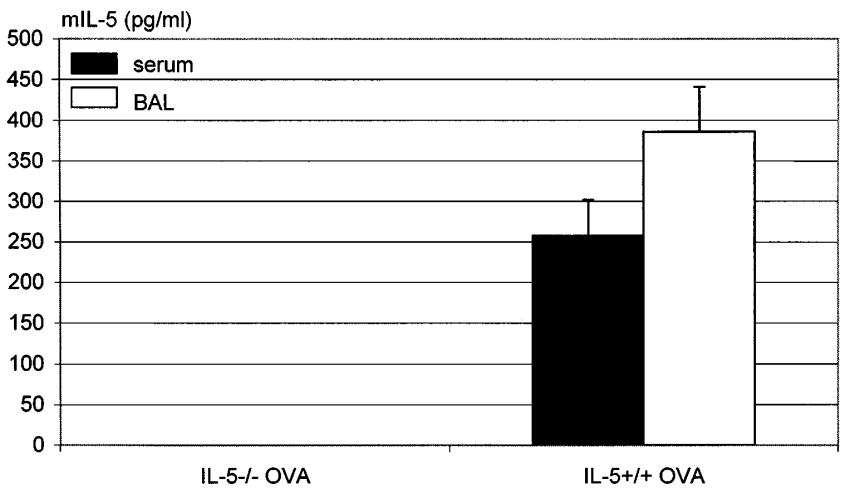

Figure 4. Comparison of IL-5 content in the BAL and serum between IL-5 $5^{-/-}$and IL- $5^{+/+}$mice. BAL fluids and sera were collected $1 \mathrm{~d}$ after OVA challenge from IL- $5^{-/-}$and $\mathrm{IL}-5^{+/+}$mice, and IL-5 content was determined by ELISA. Data represent mean \pm SEM from three mice per group.

AdIL-5 were given i.m. to naive C57BL/6 mice, and sera were collected at $24 \mathrm{~h}$ and measured for murine IL-5 by ELISA. We have previously demonstrated that by this approach, transgene is localized to the muscle with active release of transgene protein into the circulation for a period of 10 to $12 \mathrm{~d}$ (27). The circulating level of IL-5 displayed a dose-dependent pattern (Fig. 5) with $\sim 350 \mathrm{pg} / \mathrm{ml}$ being measured after delivery of a dose of $0.1 \times 10^{9} \mathrm{pfu}$ of AdIL-5, a level similar to that detected in IL$5^{+/+}$mice during OVA-induced immune-inflammatory responses. This dose was thus chosen for i.m. delivery in IL- $5^{-/-}$ mice in the following experiments. In a kinetic study, the level of IL-5 in the circulation was observed to peak at day 1, decrease but still remain significant by day 5 , and markedly decline close to background by day 8 after i.m. IL-5 gene transfer (not shown).

Reconstitution of antigen-induced airways eosinophilia by intramuscular IL-5 gene transfer in IL-5 $5^{-/}$mice. We then investigated whether circulating IL-5, in the absence of local IL-5 in the lung, was sufficient to reconstitute antigen-induced airways eosinophilia in antigen-sensitized/challenged IL- $5^{-/-}$ mice by using AdIL-5. Intramuscular gene transfer to naive IL- $5^{-1-}$ mice of a dose of $0.1 \times 10^{9} \mathrm{pfu}$ AdIL-5 led to highly compartmentalized IL-5 levels in the circulation with $350 \mathrm{pg} / \mathrm{ml}$ measured in serum but little in BAL fluids at the peak time (Fig. 6). This dose of AdIL-5 or control vector Addl70-3 was then injected i.m. to OVA-sensitized IL- $5^{-1-}$ mice at day -5
(Fig. 1). Delivery of AdIL-5 at day -5 was to ensure that the bone marrow eosinophil progenitors be stimulated by IL- 5 before OVA challenge. Our previous study has suggested the involvement of an early IL-5 response in eosinophil responses in the bone marrow and peripheral blood before the onset of airways eosinophilia by OVA aerosol challenge (10). On examination of cellular responses in the BAL at day 3 after OVA challenge, we observed a lack of airways eosinophilia in IL- $5^{-1-}$ mice receiving no vector or i.m. Addl70-3 control vector. In contrast, airways eosinophilia was fully reconstituted in the lung of IL-5 $5^{-1-}$ mice receiving i.m. delivery of AdIL-5, compared with that in IL-5 $5^{+/+}$mice (Fig. $7 A$ ). The number of other leukocyte types was similar among various groups. To examine whether such antigen-induced airways eosinophilia could persist without IL-5 present in the local lung tissue, cellular profiles in BAL obtained at $7 \mathrm{~d}$ after OVA challenge were analyzed. The number of eosinophils still remained markedly increased in the lung of $\mathrm{IL}-5^{-1-}$ mice receiving AdIL-5 (Fig. 7 B). This level of lung eosinophilia, albeit somewhat lower, was still comparable with that in the lung of IL- $5^{+/+}$ mice. We next examined histopathology of lung tissues obtained at day 3 after OVA challenge. In accord with BAL cytologic analysis, while there were similar degrees of perivascular and peribronchial accumulation of lymphocytes, neutrophils, and monocytes in the lung of both IL- $5^{+/+}$and IL- $5^{-/-}$mice, there were few eosinophils seen in the lung of IL- $5^{-1-}$ mice, in sharp contrast to significant accumulation of eosinophils in the lung of IL- $5^{+/+}$mice (Fig. 8, $a$ and $b$ ). However, intramuscular IL-5 gene transfer but not Addl70-3 administration fully reconstituted airways eosinophilia in lung tissues of IL-5 $5^{-1-}$ mice (Fig. 8, $c$ and $d$ ). Such differences were further confirmed by counting the number of eosinophils per high power field in peribronchial regions on multiple tissue sections. On average, we enumerated $3,51,3$, and 33 eosinophils per high power field in the lung of IL- $5^{-/-}$, IL- $5^{+/+}$, IL-5 $5^{-1-}$ i.m. dl70-3, and IL-5 ${ }^{-1-}$ i.m. AdIL-5 mice, respectively.

Reconstitution of bone marrow and peripheral blood eosinophilia by intramuscular IL-5 gene transfer. To investigate the mode by which circulating transgene protein IL-5 reconstituted antigen-induced airways eosinophilia in IL- $5^{-1-}$ mice, we examined the eosinophilic response both in the bone marrow and peripheral blood. At $3 \mathrm{~d}$ after OVA challenge, there was a minimal increase in eosinophil percentage in bone marrow of IL-5 ${ }^{-1-}$ mice without or with i.m. Addl70-3 control vector treatment. In contrast, the level of eosinophilia markedly increased in the bone marrow of IL- $5^{-/-}$mice receiving i.m. IL-5

Table I. The Comparison of Cellular Responses in the Peripheral Blood of IL-5 $5^{+/+}$and IL-5 $5^{-/-}$Mice $\left(\times 10^{4} / \mathrm{ml}\right)$

\begin{tabular}{|c|c|c|c|c|}
\hline & \multicolumn{2}{|c|}{$5 \mathrm{~d}$ before OVA challenge } & \multicolumn{2}{|c|}{$3 \mathrm{~d}$ after OVA challenge } \\
\hline & $\mathrm{IL}-5^{+/+}$ & $\mathrm{IL}-5^{-/-}$ & ${\mathrm{IL}-5^{+/+}}$ & $\mathrm{IL}-5^{-/-}$ \\
\hline Total WBC & $614.25 \pm 15.75$ & $687.75 \pm 153$ & $945 \pm 146.8$ & $759.5 \pm 162.1$ \\
\hline Lymphocyte & $533.05 \pm 17.02$ & $614.55 \pm 146.2$ & $795.36 \pm 116.8$ & $686.16 \pm 154.31$ \\
\hline Monocyte & $9.73 \pm 3.45$ & $11.94 \pm 2.21$ & $21.0 \pm 5.61$ & $9.75 \pm 6.07$ \\
\hline Neutrophil & $51.55 \pm 1.14$ & $58.42 \pm 12.47$ & $97.41 \pm 23.64$ & $49.08 \pm 4.27$ \\
\hline Eosinophil & $19.33 \pm 3.77^{*}$ & $2.85 \pm 0.47$ & $31.27 \pm 9.42 *$ & $1.49 \pm 0.87$ \\
\hline
\end{tabular}

Heparinized whole blood was collected at noted times. Total leukocytes (WBC) were determined after red blood cells lysis with RBC lysis buffer and differentials determined on Diff-Quik-stained blood smears. Data represent mean \pm SEM from three IL- $5^{-1-}$ and five IL-5 $5^{+/+}$mice. $* P<0.05$ as compared to IL-5 ${ }^{-/-}$group. 


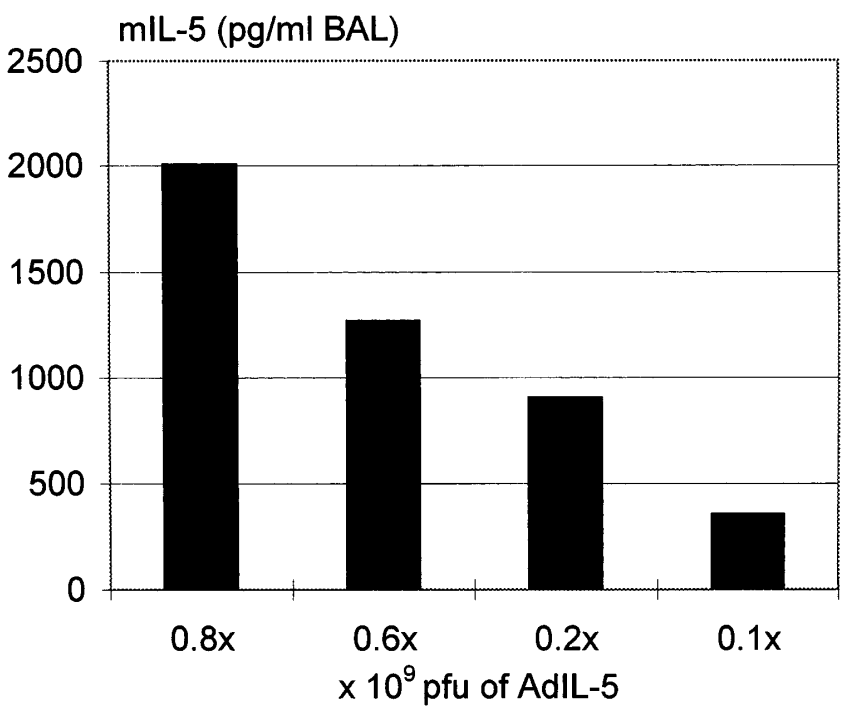

Figure 5. In vivo characterization of AdIL-5. Various doses of AdIL-5 were giving i.m. to naive C57BL/6 mice and sera collected at $24 \mathrm{~h}$ were measured for mIL-5 by ELISA. Results represent mean values from two mice per dose.

gene transfer, similar to that in $\mathrm{IL}-5^{+/+}$mice (Fig. 9 A). Accompanied with eosinophilic responses in the bone marrow was a peripheral blood eosinophilia in $\mathrm{IL}-5^{-1-}$ mice receiving IL-5 i.m. gene transfer, the level of which also increased to that in IL- $5^{+/+}$mice (Fig. $9 \mathrm{~B}$ ). These were in contrast to the lack of peripheral blood eosinophilia in IL- $5^{-/-}$mice without or with i.m. delivery of Add170-3.

Similar levels of IL-4 and chemokines eotaxin and MIP-1 $\alpha$ in the lung of $I L-5^{+/+}$and $I L-5^{-/-}$mice. These results have thus far indicated that circulating IL-5, via its effects on bone marrow and peripheral blood eosinophils, is a systemic signal required for the development of antigen-induced airways eosinophilia, which can occur in the absence of local levels of IL-5 in the lung. It is believed, however, that certain local tissue signals are required for circulating eosinophils to migrate across the vasculature into the airways. In this regard, IL-4, in addi-

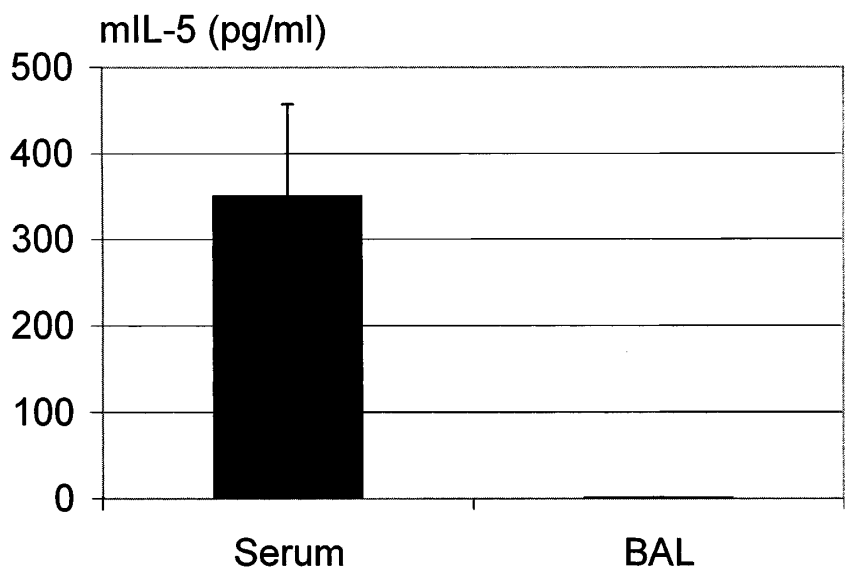

Figure 6. Compartmentalized distribution of transgene protein IL-5 in BAL after i.m. administration of AdIL-5 $\left(0.1 \times 10^{9} \mathrm{pfu}\right)$ in IL-5 ${ }^{-/}$ mice. BAL fluids and sera were collected at $24 \mathrm{~h}$ and assayed for mIL- 5 by ELISA. Data are expressed as mean \pm SEM from five mice.
A
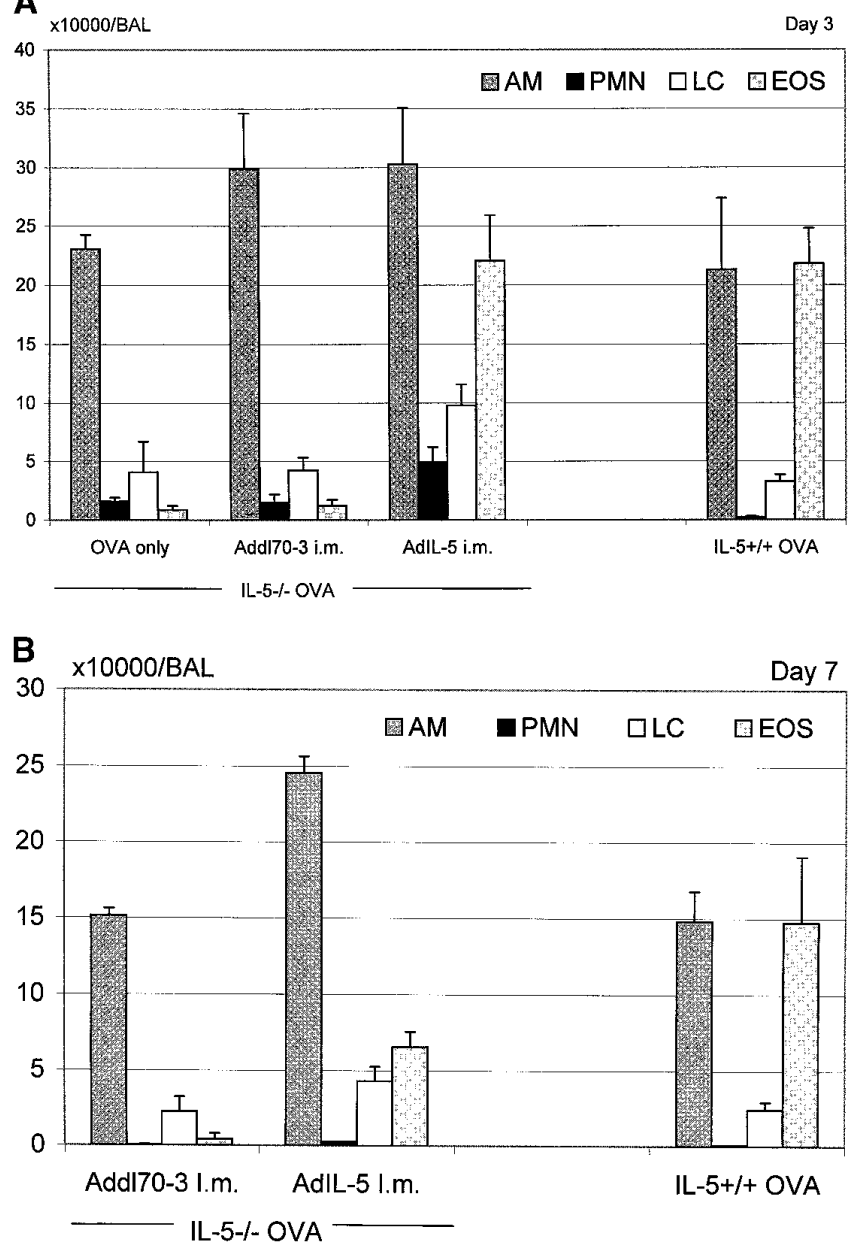

Figure 7. Reconstitution of OVA-induced airways eosinophilia by i.m. IL-5 gene transfer in OVA-sensitized IL- $5^{-/-}$mice. Cellular responses were determined with BAL cell preparations by cell differential counting. $(A)$ day 3 after challenge; OVA only $(n=3)$, Addl70-3 i.m. $(n=5)$, AdIL-5 i.m. $(n=6)$, IL-5 $5^{+/+}$OVA $(n=5)$. (B) day 7 after challenge; Addl70-3 i.m. $(n=3)$, AdIL-5 i.m. $(n=4)$, IL- $5^{+/+}$OVA $(n=4)$. Results represent mean \pm SEM. The degree of eosinophilia between IL-5 $5^{-/}$AdIL-5 and IL-5 $5^{-/}$Add170-3 groups is statistically significantly different $(P=0.011)$ but is not statistically different between IL-5 ${ }^{-/-}$OVA/AdIL-5 and IL- $5^{+/+}$OVA groups $(P=0.16)$.

tion to its other activities, enhances eosinophil adhesion to the endothelium by upregulating VCAM-1 expression (31), and C-C chemokines eotaxin and MIP- $1 \alpha$ have chemotactic effects on eosinophils $(32,33)$. We measured the content of IL-4, eotaxin, and MIP- $1 \alpha$ in BAL fluids collected at day 1 after OVA challenge from IL-5 $5^{+/+}$and IL-5 $5^{-/-}$mice. While very little IL-4 was measured in BAL from both naive IL-5 $5^{-/-}$and IL-5 $5^{+/+}$ mice, similarly increased levels of IL- 4 were measured in BAL fluids collected from OVA-sensitized/challenged IL- $5^{+/+}$mice and IL-5 $5^{-1-}$ mice with or without i.m. delivery of AdIL-5 or Add170-3 (Table II). Similar induction of chemokines eotaxin and MIP- $1 \alpha$ was also observed in BAL fluids from both IL- $5^{+/+}$ mice and IL- $5^{-1-}$ mice under these conditions (Table II). Similar levels of immune responses were further supported by similar anti-OVA IgE responses between $\mathrm{IL}-5^{+/+}$and $\mathrm{IL}-5^{-1-}$ mice, $137.7 \pm 37.5,219.9 \pm 92.8,161.7 \pm 60.1 \mathrm{ng} / \mathrm{ml}$ serum in 

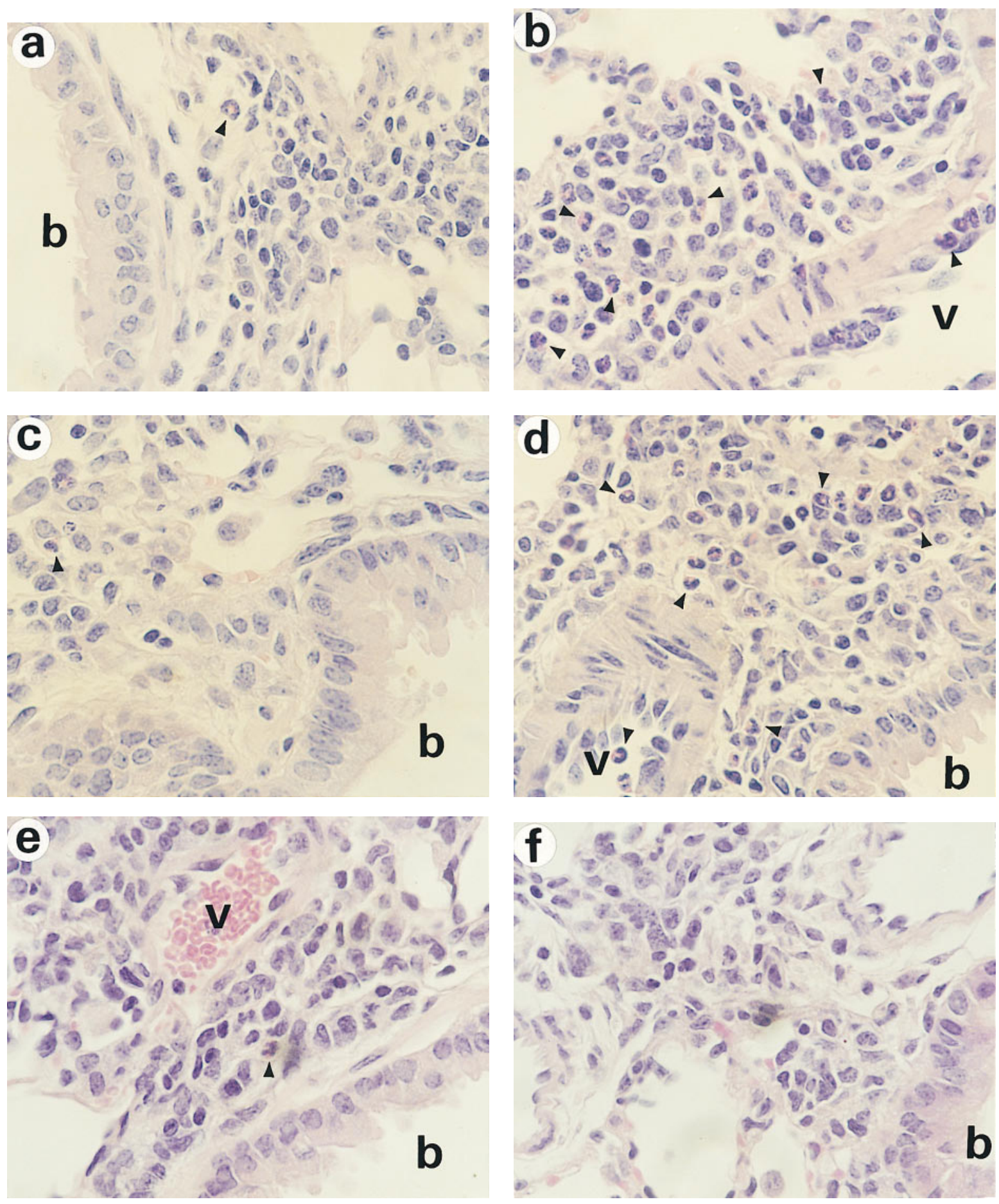

Figure 8. Histopathologic changes in the lung. Lung tissues were obtained at day 3 after OVA challenge from IL- $-5^{-/-}$mice $(a)$, IL-5 $5^{+/+}$mice $(b)$, IL-5 ${ }^{-/-}$mice with i.m. Addl70-3 (c), IL-5 ${ }^{-/-}$mice with i.m. AdIL-5 $(d)$, IL-5 ${ }^{-/-}$mice with i.n. Addl70-3 (e) or IL-5 ${ }^{-/-}$mice with i.n. AdIL-5 delivery $(f)$. There is a marked infiltration of mononuclear cells with few eosinophils seen in Fig. 8, $a, c, e$, and $f$. In contrast, marked airways eosinophilia is seen in Fig. 8, $b$ and $d$. Some eosinophils are marked with arrowheads. Bronchial and vascular structures are marked by $\mathrm{b}$ and $\mathrm{v}$, respectively. (Magnification for all panels is 950.)

IL-5 $5^{+/+}$, IL-5 $5^{-1-}$, and IL-5 ${ }^{-/-}$i.m. AdIL-5 mice, respectively (day 1 after OVA challenge).

Lack of reconstitution of antigen-induced airways eosinophilia following compartmentalized intrapulmonary IL-5 gene transfer in $\mathrm{IL}-5^{-/-}$mice. Our findings have thus far strongly suggested that if only present locally in the lung but not in the circulation, IL-5 cannot reconstitute airways eosinophilia in IL- $5^{-1-}$ mice. To demonstrate this, we delivered a dose of $0.12 \times 10^{9}$ pfu of AdIL-5 i.n. into the lung of IL-5 $5^{-1-}$ mice at day -3 (Fig. 1). We have previously shown that by this approach the level in BAL of transgene protein peaks at $\sim$ day 4 (28); thus, delivering AdIL-5 3 d before OVA challenge would 
A \% of eosinophils in bone marrow

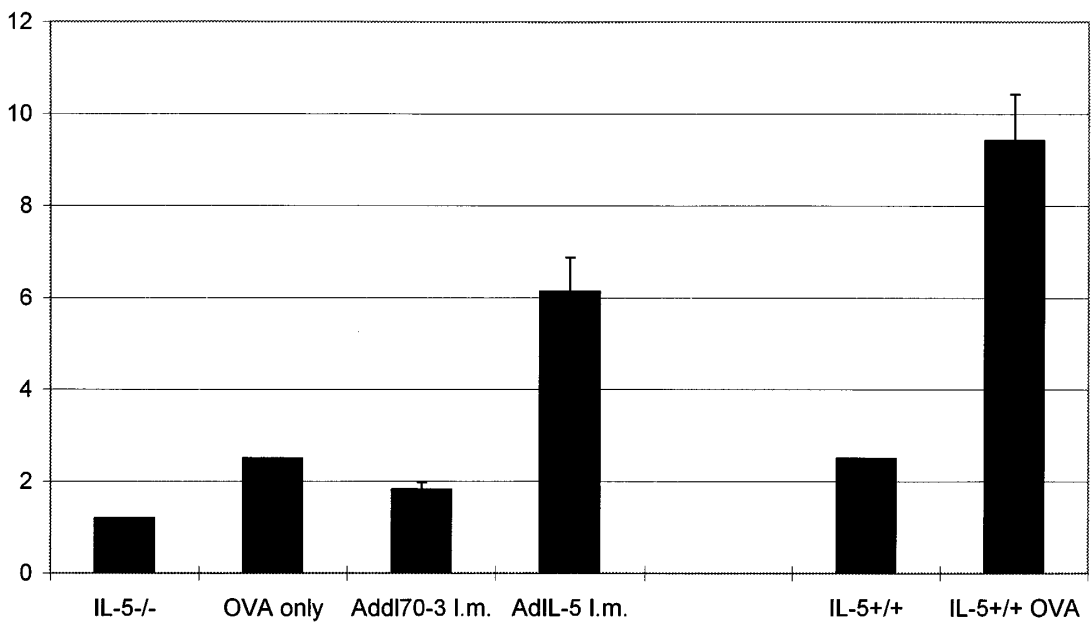

IL-5-I- OVA

B eosinophils (x10000/ml)

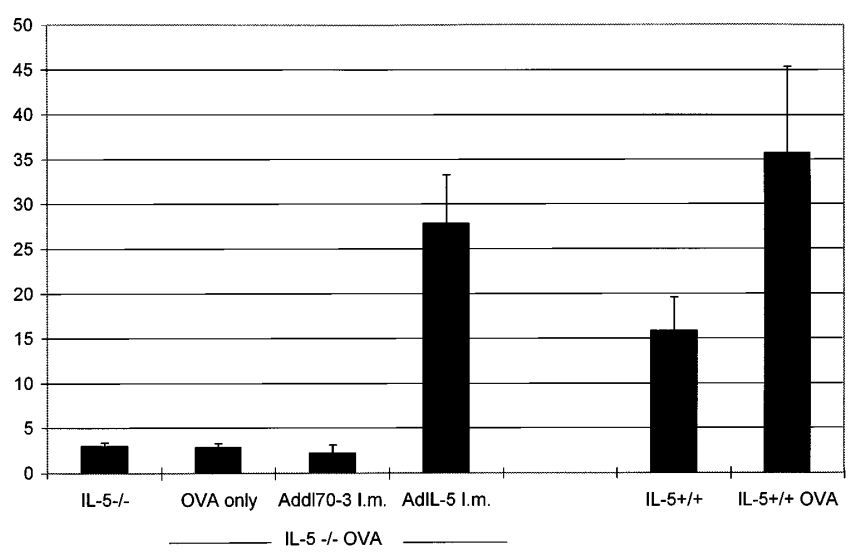

allow a maximal level of transgene protein IL-5 present in the lung at day 1 after OVA challenge in IL- $5^{-1-}$ mice. By delivering $0.12 \times 10^{9} \mathrm{pfu}$ of AdIL-5, a significant level of IL-5 was measured in BAL fluids collected at day 4, which led to little spill of IL-5 into the circulation in IL- $5^{-1-}$ mice (Table III). This level of compartmentalized IL-5 transgene protein in the lung

Table II. The Content of Cytokines in BAL $(\mathrm{pg} / \mathrm{ml})$

\begin{tabular}{cccc}
\hline & IL-4 & Eotaxin & \multicolumn{1}{c}{ MIP-1 $\alpha$} \\
\hline IL-5 & \\
IL- $5^{-/-}$OVA & $495.25 \pm 170.94$ & $131.72 \pm 41.02$ & $20.27 \pm 2.86$ \\
$\quad$ Add170-3 i.m. & $689.71 \pm 310.29$ & $96.62 \pm 45.58$ & $50.58 \pm 20.91$ \\
IL-5 $5^{-/-}$OVA & & & \\
AdIL-5 i.m. & $455.95 \pm 272.21$ & $29.63 \pm 2.3$ & $18.14 \pm 6.7$ \\
IL-5 $5^{+/+}$OVA & $378.55 \pm 103.58$ & $24.39 \pm 3.74$ & $17.83 \pm 4.63$
\end{tabular}

BAL fluids were collected at day 1 after OVA-challenge. IL-4, eotaxin and MIP- $1 \alpha$ were measured by specific ELISA. Data represent mean \pm SEM from IL- $5^{-1-}$ OVA $(n=3), \mathrm{IL}^{-5^{-1}}$ OVA Add170-3 $(n=$ $3), \mathrm{IL}^{-5^{-1}}$ OVA AdIL-5 $(n=3)$ and IL- $5^{+/+}$OVA $(n=4)$ mice. There is no statistically significant difference between treatments. The levels of these cytokines in BAL from naive IL- $5^{-/-}$or IL- $5^{+/+}$mice were under or close to the assay detection limit.
Figure 9. Peripheral eosinophilic responses in IL- $5^{-/-}$and IL-5 $5^{+/+}$mice. The level of eosinophilia in bone marrow $(A)$ and peripheral blood $(B)$ was analyzed from indicated groups at day 3 after OVA challenge. The number of mice used for each group was identical to that indicated for Fig. 7 A. Data represent mean \pm SEM. There is no statistically significant difference between IL- $5^{-/-}$OVA/AdIL-5 and IL-5 $5^{++}$OVA groups.

failed to reconstitute antigen-induced airways eosinophilia as shown by BAL cellular analysis (Fig. 10). The lack of eosinophilic responses under such conditions was further supported by histologic examination (Fig. 8, $e$ and $f$ ). In keeping with these findings, there were minimal increases in the number of eosinophils in the bone marrow and peripheral blood (data not shown).

\section{Discussion}

In this study, we demonstrated that, in contrast to their IL- $5^{+/+}$ counterparts, the lack of IL- 5 response both in the lung and

Table III. IL-5 Levels in BAL and Serum Post-i.n. AdIL-5 Delivery in $\mathrm{IL}-5^{-/-}$Mice

\begin{tabular}{|c|c|c|c|}
\hline & BAL & Serum & No. of mice \\
\hline IL-5 $5^{-/-}$Add170-3 & 0 & 0 & 4 \\
\hline IL-5 ${ }^{-/-}$AdIL-5 & $49.8 \pm 18$ & $4.5 \pm 1.9$ & 9 \\
\hline
\end{tabular}

BAL fluids and sera were collected at day 4 post-i.n. delivery of AdIL-5 or control vector Addl70-3 and measured for IL-5 content by ELISA. Results are expressed as mean \pm SEM. The limit of assay detection is 5 $\mathrm{pg} / \mathrm{ml}$. 


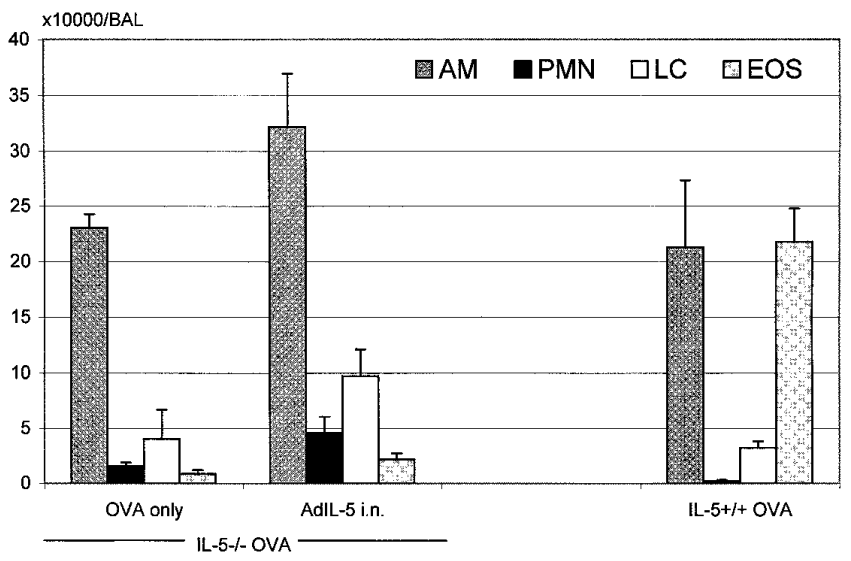

Figure 10. Lack of reconstitution of OVA-induced airways eosinophilia by i.n. IL-5 gene transfer in IL- $5^{-/}$mice. BAL were obtained $3 \mathrm{~d}$ after OVA challenge, and cytologic analysis was performed by cell differential counting. Results are expressed as mean \pm SEM from four (OVA only), nine (AdIL-5 i.n.), and six (IL-5 $5^{+/+} \mathrm{OVA}$ ) mice. There is no statistically significant difference in the number of eosinophils between IL-5 ${ }^{-/-}$OVA and IL-5 ${ }^{-/-}$OVA/AdIL-5. The difference in the number of eosinophils between IL- $5^{-/-}$OVA or IL-5 $5^{--}$ OVA/AdIL-5 and IL- $5^{+/+}$OVA groups is statistically significant $(P<$ $0.003)$.

peripheral blood in IL-5 $5^{-/-}$mice resulted in a lack of peripheral and airways eosinophilia in response to antigen sensitization and challenge, whereas the response of lymphocytes, neutrophils, and macrophages, and the level of IL-4 and chemokines in the lung were not markedly weakened in these mice. Circulating IL- 5 by intramuscular IL- 5 gene transfer to antigen-sensitized IL- $5^{-1-}$ mice reconstituted eosinophilia not only in the bone marrow and peripheral blood but also in the airway upon antigen challenge. In contrast, local compartmentalized IL-5 achieved by intrapulmonary IL-5 gene transfer to these mice was unable to reconstitute airways eosinophilia, which was associated with a failure in reconstituting bone marrow and peripheral blood eosinophilia. These findings indicate a critical role of circulating IL-5 in the development of antigen-induced airways eosinophilia and suggest that, contrary to previously thought, local lung IL-5 plays a relatively less important role in the process of eosinophil accumulation in the airways.

IL-5, GM-CSF, and IL-3 are members of the hematopoietic growth factor family. Different from GM-CSF and IL-3, IL-5 has restricted biologic effects, primarily on eosinophils and eosinophil progenitors $(2,3)$. IL-5 has been shown to stimulate the differentiation of eosinophil progenitor cells in vitro and in systemic IL-5 transgenic mice $(11,13)$. In contrast to marked peripheral blood eosinophilia in IL-5 transgenic mice, GMCSF transgenic mice developed only mild peripheral blood eosinophilia, together with markedly increased numbers of neutrophils and monocytes (34). However, IL-5 is not merely an eosinopoietic growth factor since a wealth of in vitro evidence has suggested that it is also an eosinophil chemoattractant and survival factor (14-17). Indeed, the level of IL-5 is increased in the peripheral blood and local lung tissue both in asthmatic patients and experimental models of asthmatic inflammation (5-10). And recently, IL-5, but not IL-3, receptor expression on $\mathrm{CD}_{3} 4^{+}$progenitors and the number of eosino- phil progenitor cells in the bone marrow have been found markedly increased in mild asthmatic patients upon local lung allergen challenge $(35,36)$. Thus, the role of IL-5 in the pathogenesis of allergic asthma has been thought to be mediated through its effects not only on eosinophil differentiation in the bone marrow but also on eosinophil influx and survival locally in the lung $(1-4,17)$. This notion appears to be supported by further experimental observations. Systemic administration of anti-IL-5 monoclonal antibodies inhibited antigen-induced airways eosinophilia (22-24); IL-5 ${ }^{-1-}$ mice failed to mount antigen-induced airways eosinophilia unless an IL-5 gene transfer vector was repeatedly intranasally delivered before and during antigen challenge (21); overexpression of IL-5 locally in the lung, either by delivering repeated large doses of recombinant IL-5 (37), or gene transfer vectors (19), or in lung-specific IL-5 transgenic mice (20), induced airways eosinophilia. However, systemically delivered antibodies will abrogate not only circulating IL-5 but also local lung IL-5. High levels of local overexpression of IL-5 result in not only higher than physiologic levels of IL-5 protein in the lung, but also spillovers of IL-5 into the circulation; induction of airways eosinophilia was invariably associated with an increased number of peripheral blood eosinophils (19-21). On the other hand, since IL-5 was shown to be chemotactic to eosinophils in vitro only when present at much higher concentrations compared with classic eosinophil chemoattractants (17), it is very likely that the influx of eosinophils into the airways occurs as a result of eosinophil chemotaxis to transgenic levels of IL-5 in the lung, which may not represent a physiologic functional aspect of IL-5 during immune-inflammatory responses. Hence, the relative role of local and systemic IL-5 in allergic airways eosinophilia remains to be clarified.

To dissect the role of local and systemic IL-5 in the pathogenesis of allergic airways eosinophilia, we first examined the cellular and cytokine responses in OVA-sensitized and challenged IL-5-deficient mice. Consistent with a previous study (21), we found a lack of airways and peripheral blood eosinophilia in IL-5 $5^{-1-}$ mice. However, in contrast to that study, we found similar responses of other leukocyte subsets including lymphocytes, neutrophils, and macrophages both in BAL and lung tissues. Such discrepancies are likely due to differences in the protocol for sensitization and challenge. Upon examination of cytokines, we found significantly increased levels of IL-5 in BAL and peripheral blood in IL- $5^{+/+}$mice but not in IL$5^{-1-}$ mice upon OVA challenge. In contrast, the level of another Th2 cytokine IL-4 and CC chemokines eotaxin and MIP$1 \alpha$ in the lung was similar between IL- $5^{+/+}$and IL- $5^{-/-}$mice, thus likely explaining the similar extent of airways inflammatory responses of lymphocytes, neutrophils, and macrophages. Of interest, although not statistically significant, there appeared lower levels of eotaxin in the lung of mice with airways eosinophilia (IL-5 $5^{+/+}$OVA or IL-5 $5^{-1-}$ OVA AdIL-5 i.m.) as compared with those in mice without airways eosinophilia. This may not reflect a lower production but rather suggests a greater consumption of eotaxin in the lung by infiltrating eosinophils. These findings, to our knowledge, represent the first experimental evidence that the lack of IL-5 and airways eosinophilia has little effect on the level of cytokines and influx of leukocytes other than eosinophils in the lung during allergic airways inflammation.

We then investigated the role of local and systemic IL-5 in allergic airways eosinophilia by using an IL-5 transgene ap- 
proach in sensitized IL-5 $5^{-1-}$ mice. Intramuscular delivery of an IL-5 gene transfer vector led to raised IL-5 levels compartmentalized to the peripheral blood compartment and completely reconstituted airways eosinophilia in $\mathrm{IL}-5^{-1-}$ mice after OVA challenge. Of importance, such a reconstitution of airways eosinophilia was associated with a restored eosinophilic response in the bone marrow and peripheral blood. The magnitude of airways eosinophilia was identical or even slightly higher than that seen in IL- $5^{+/+}$mice at day 3 after OVA challenge ( $8 \mathrm{~d}$ after i.m. IL-5 gene transfer). It is noteworthy that circulating levels of transgene protein IL-5 in IL- $5^{-1-}$ mice during the period from OVA challenge (day 0) to death (day 3) had declined towards the baseline (5-8 d after i.m. gene transfer). This suggests that the eosinophil priming or mobilizing effect by systemic IL-5 before OVA-aerosol challenge is of critical importance in the onset of airways eosinophilia. Indeed, we observed an increase in the number of peripheral blood eosinophils in OVA-sensitized IL- $5^{+/+}$mice before OVA challenge. Furthermore, it suggests that high circulating levels of IL-5 that emerge and peak around day 1 after OVA challenge in IL- $5^{+/+}$mice are not required for the peak airways eosinophilic response (day 3). On the other hand, our finding that full reconstitution of airways eosinophilia in IL- $5^{-1-}$ mice by i.m. IL-5 gene transfer took place in the absence of lung tissue IL-5, indicates that local lung IL-5 is not required for the development of a full-blown antigen-induced airways eosinophilia. Such dissociability of antigen-induced airways eosinophilia from significant tissue levels of IL-5 in the lung is further supported by our observation that there was still marked airways eosinophilia in IL-5 $5^{-1-}$ mice receiving i.m. IL-5 gene transfer $7 \mathrm{~d}$ after OVA challenge. This latter finding also suggests a significant role of molecules other than IL-5 in the perpetuation of airways eosinophilia during asthmatic inflammation. While it remains to be determined whether i.m. IL-5 gene transfer concurrently reconstituted airways hyperreactivity in IL-5 ${ }^{-1-}$ mice, a recent study in a different model system has suggested that systemic IL-5, in the presence of specific $\operatorname{IgE}$, is also involved in enhanced airways reactivity (38). With establishment of the critical role of systemic IL-5 in airways eosinophilia, we explored the potential mechanisms within the lung by which eosinophils migrated into the airways despite the absence of local IL-5. We found that the level of IL-4, eotaxin, and MIP$1 \alpha$ was not compromised in the lung of antigen-challenged IL$5^{-1-}$ mice, thus indicating that other eosinophil-active cytokines are fully capable of mounting airways eosinophilia in the absence of local IL-5. We have recently found that IL-4, together with $\mathrm{TNF} \alpha$, is required for VCAM-1 upregulation on pulmonary vasculature, which is in turn required for the development of allergic airways eosinophilia (39). Eosinophil chemokines including eotaxin and MIP-1 $\alpha$ have been shown involved in eosinophil chemotaxis in the lung during allergic airways inflammation $(32,33,40-42)$. In addition, we have previously shown that there is a small but significant level of GMCSF being induced in the lung during allergic airways inflammation (10). It is thus possible that GM-CSF implements many biologic activities that IL-5 is capable of in this model. The requirement of such coordination between systemic IL-5 and local lung cytokines such as eotaxin for the onset of airways eosinophilia is also supported by recent findings from skin models (43-45).

Thus, we have demonstrated that circulatory but not local lung IL-5 is critically required for the development of antigen- induced airways eosinophilia via its effect on bone marrow and peripheral blood eosinophils. On the other hand, local cytokine signals in the absence of IL-5 are sufficient to set up a stage for airway eosinophil accumulation to take place. While these findings shall not dismiss the possible potentiating/activating activities by local lung IL-5, together with other cytokines, on accumulating eosinophils in asthmatic airways tissues, they provide important rationale for developing strategies to target circulating, rather than local, IL-5, or its receptors in $\mathrm{BM}$ to effectively control asthmatic airways eosinophilia, particularly in steroid-resistant asthmatics.

\section{Acknowledgments}

We wish to thank Anna Zganiacz, Xueya Feng, Duncan Chong, Jennifer Wattie, Sussana Goncharova, Scott Neigh, and Bruce Vallance for their invaluable help. We also thank Dr. Todd Braciak for his initial contribution to the construction of plasmids and Sara DeSilvio for her secretarial assistance.

This study is supported by the Medical Research Council (MRC) of Canada and Astra Draco AB, Sweden. M. Jordana is a Career Scientist of the Ontario Ministry of Health. Z. Xing is a scholar of MRC, Canada.

\section{References}

1. Seminario, M.-C., and G.J. Gleich. 1994. The role of eosinophils in the pathogenesis of asthma. Curr. Opin. Immunol. 6:860-864.

2. Bochner, B.S., B.J. Undem, and L.M. Lichtenstein. 1994. Immunological aspects of allergic asthma. Annu. Rev. Immunol. 12:295-335.

3. Anderson, G.P. 1995. Eosinophilia in genetically altered mice. Eur. Respir. Rev. 29:231-237.

4. Robinson, D.S., S.R. Durham, and A.B. Kay. 1993. Cytokines in asthma. Thorax. 48:845-853.

5. Hamid, Q., M. Azzawi, S. Ying, R. Moqbel, A.J. Wardlaw, C.J. Corrigan, B. Bradley, S.R. Durham, J.V. Collins, P.K. Jeffery, et al. 1991. Expression of mRNA for interleukin-5 in mucosal bronchial biopsies from asthma. J. Clin. Invest. $87: 1541-1546$.

6. Robinson, D.S., Q. Hamid, S. Ying, A. Tsicopoulos, J. Barkans, A.M. Bentley, C. Corrigan, S.R. Durham, and A.B. Kay. 1992. Predominant TH2-like bronchoalveolar T-lymphocyte population in atopic asthma. N. Engl. J. Med. 30:298-304.

7. Walker, C., E. Bode, L. Boer, T.T. Hansel, K. Blaser, J.C. Virchow, Jr. 1992. Allergic asthmatics have distinct patterns of T-cell activation and cytokine production in peripheral blood and bronchoalveolar lavage. Am. Rev. Respir. Dis. 146:109-115.

8. Alexander, A.G., J. Barkans, R. Moqbel, N.C. Barnes, A.B. Kay, and C.J. Corrigan. 1994. Serum interleukin-5 concentrations in atopic and nonatopic patients with glucocorticoid-dependent chronic severe asthma. Thorax. 49:1231-1233

9. Yamaguchi, S., H. Nagai, H. Tanaka, M. Tsujimoto, and N. Tsuruoka. 1994. Time course study for antigen-induced airway hyperreactivity and the effect of soluble IL-5 receptor. Life Sci. 54:471-475.

10. Ohkawara, Y., X.-F. Lei, M.R. Stampfli, J.S. Marshall, Z. Xing, and M Jordana. 1997. Cytokine and eosinophil responses in the lung, peripheral blood, and bone marrow compartments in a murine model of allergen-induced airways inflammation. Am. J. Respir. Cell Mol. Biol. 16:510-520.

11. Clutterbuck, E.J., and C.J. Sanderson. 1988. Human eosinophil hematopoiesis studies in vitro by means of murine eosinophil differentiation factor (IL-5): production of functionally active eosinophils from normal human bone marrow. Blood. 71:646-651.

12. Kopf, M., F. Brombacher, P.D. Hodgkin, A.J. Ramsay, E.A. Milbourne, W.J. Dai, K.S. Ovington, C.A. Behm, G. Kohler, I.G. Young, et al. 1996. IL-5 deficient mice have a developmental defect in $\mathrm{CD}^{+} \mathrm{B}-1$ cells and lack eosinophilia but have normal antibody and cytotoxic T cell responses. Immunity. 4:15-24.

13. Lee, N.A., M.P. McGarry, K.A. Larson, M.A. Horton, A.B. Kristensen, and J.J. Lee. 1997. Expression of IL-5 in thymocytes/T cells leads to the development of a massive eosinophilia, extramedullary eosinophilopoiesis, and unique histopathologies. J. Immunol. 158:1332-1344.

14. Yamaguchi, Y., Y. Hayashi, Y. Sugama, Y. Miura, T. Kasahara, S. Kitamura, M. Torisu, S. Mita, A. Tominaga, K. Takatsu, et al. 1988. Highly purified murine interleukin-5 (IL-5) stimulates eosinophil function and prolongs in vitro survival. IL-5 as an eosinophil chemotactic factor. J. Exp. Med. 167:1737-1742.

15. Wang, J.M., A. Rambaldi, A. Biondi, Z.G. Chen, C.J. Sanderson, and A. 
Mantovani. 1989. Recombinant human interleukin 5 is a selective eosinophil chemoattractant. Eur. J. Immunol. 19:701-705.

16. Tai, P.C., L. Sun, and C.J.F. Spry. 1991. Effects of IL-5, granulocyte/ macrophage colony-stimulating factor (GM-CSF) and IL-3 on the survival of human blood eosinophils in vitro. Clin. Exp. Immunol. 85:312-316.

17. Resnick, M.R., and P.F. Weller. 1993. Mechanisms of eosinophil recruitment. Am. J. Respir. Cell Mol. Biol. 8:349-355.

18. Dent, L.A., M. Strath, A.L. Mellor, and C.J. Sanderson. 1990. Eosinophilia in transgenic mice expressing interleukin-5. J. Exp. Med. 172:1425-1431.

19. Xing, Z., Y. Ohkawara, T. Braciak, G.M. Tremblay, P.J. Sime, M. Jordana, and J. Gauldie. 1996. Disparate functional consequences of transient overexpression of GM-CSF and IL-5 in the lung. Am. J. Respir. Crit. Care Med. 153:A793.

20. Lee, J.J., M.P. McGarry, S.C. Farmer, K.L. Denzler, K.A. Larson, P.E. Carrigan, I.E. Brenneise, M.A. Horton, A. Haczku, E.W. Gelfand, et al. 1997. Interleukin-5 expression in the lung epithelium of transgenic mice leads to pulmonary changes pathognomonic of asthma. J. Exp. Med. 185:2143-2154.

21. Foster, P.S., S.P. Hogan, A.J. Ramsay, K.I. Matthaei, and I.G. Young. 1996. Interleukin 5 deficiency abolished eosinophilia, airways hyperreactivity, and lung damage in a mouse asthma model. J. Exp. Med. 183:195-201.

22. Coffman, R.L., B.W. Seymour, S. Hudak, J. Jackson, and D. Rennick. 1989. Antibody to interleukin-5 inhibits helminth-induced eosinophilia in mice. Science. 245:308-310.

23. Mauser, P.J., A.M. Pitman, X. Fernandez, S.K. Foran, G.K. Adams III, W. Kreutner, R.W. Egan, and R.W. Chapman. 1995. Effects of an antibody to interleukin-5 in a monkey model of asthma. Am. J. Respir. Crit. Care Med. 152: $467-472$.

24. Kung, T.T., D.M. Stelts, J.A. Zurcher, G.K. Adams III, R.W. Egan, W. Kreutner, A.S. Watnick, H. Jones, and R.W. Chapman. 1995. Involvement of IL-5 in a murine model of allergic pulmonary inflammation: prophylactic and therapeutic effect of an anti-IL-5 antibody. Am. J. Respir. Cell Mol. Biol. 13: 360-365.

25. McGrory, W.J., D.S. Bautista, and F.L. Graham. 1988. A simple technique for the rescue of early region I mutations into infectious human adenovirus type 5. Virology. 163:614-617.

26. Graham, F.L., and L. Prevec. 1991. Gene transfer and expression protocols. In Methods in Molecular Biology. E.J. Murry and J.M. Walker, editors. Humana Press Inc., Clifton, NJ. 109-127.

27. Xing, Z., Y. Ohkawara, M. Jordana, F.L. Graham, and J. Gauldie. 1997. Adenoviral vector-mediated IL-10 expression in vivo: intramuscular gene transfer inhibits cytokine responses in endotoxemia. Gene Ther. 4:140-149.

28. Lei, X.-F., Y. Ohkawara, M.R. St $\alpha$ mpfli, J. Gauldie, K. Croitoru, M. Jordana, and Z. Xing. 1998. Compartmentalized transgene expression of granulocyte-macrophage colony-stimulating factor (GM-CSF) in mouse lung enhances allergic airways inflammation. Clin. Exp. Immunol. 113:157-165.

29. Stämpfli, M.R., S.A. Ritz, G.S. Neigh, P.J. Sime, X.-F. Lei, Z. Xing, K. Croitoru, and M. Jordana. 1998. Intramuscular viral infection inhibits antigeninduced airways inflammation in mice. Clin. Exp. Allergy. In press.

30. Xing, Z., T. Braciak, Y. Ohkawara, J.-M. Sallenave, R. Foley, P.J. Sime, M. Jordana, F.L. Graham, and J. Gauldie. 1996. Gene transfer for cytokine functional studies in the lung: the multifunctional role of GM-CSF in pulmonary inflammation. J. Leukoc. Biol. 59:481-488.

31. Schleimer, R.P., S.A. Sterbinsky, J. Kaiser, C.A. Bickel, D.A. Klunk, K. Tomioka, W. Newman, F.W. Luscinskas, M.A. Gimbrone, Jr., B.W. McIntyre, et al. 1992. IL-4 induced adherence of human eosinophils and basophils but not neutrophils to endothelium. Association with expression of VCAM-1. J. Immu- nol. $148: 1086-1092$.

32. Gonzalo, J.-A., G.-Q. Jia, V. Aguirre, D. Friend, A.J. Coyle, N.A. Jenkins, G-s. Lin, H. Katz, A. Lichtman, N. Copeland, et al. 1996. Mouse eotaxin expression parallels eosinophil accumulation during lung allergic inflammation but it is not restricted to a Th2-type response. Immunity. 4:1-14.

33. Lukacs, N.W., R.M. Strieter, K. Warmington, P. Lincoln, S.W. Chensue, and S.L. Kunkel. 1997. Differential recruitment of leukocyte populations and alteration of airways hyperreactivity by $\mathrm{C}-\mathrm{C}$ family chemokines in allergic airways inflammation. J. Immunol. 158:4398-4404.

34. Lang, R.A., D. Metcalf, R.A. Cuthbertson, I. Lyons, E. Stanley, A. Kelso, G. Kannourakis, D.J. Williamson, G.K. Klintworth, T.J. Gonda, et al. 1987. Transgenic mice expressing a hemopoietic growth factor gene (GM-CSF) develop accumulations of macrophages, blindness, and a fatal syndrome of tissue damage. Cell. 51:675-686.

35. Sehmi, R., L.J. Wood, R. Watson, R. Foley, Q. Hamid, P.M. O'Byrne, and J.A. Denburg. 1997. Allergen-induced increases in IL-5 receptor a-subunit expression on bone marrow-derived $\mathrm{CD} 34^{+}$cells from asthmatic subjects. $J$. Clin. Invest. 100:2466-2475.

36. Wood, L.J., M.D. Inman, R.M. Watson, R. Foley, J.A. Denburg, and P.M. O'Byrne. 1998. Changes in bone marrow inflammatory cell progenitors after inhaled allergen in asthmatic subjects. Am. J. Respir. Crit. Care Med. 157: 99-105.

37. Van Oosterhout, A.J.M., D. Fattah, I. Van Ark, G. Hofman, T.L. Buckley, and F.P. Nijkamp. 1995. Eosinophil infiltration precedes development of airway hyperreactivity and mucosal exudation after intranasal administration of interleukin-5 to mice. J. Allergy Clin. Immunol. 96:104-112.

38. Hamelmann, E., A. Oshiba, J. Schwarze, K. Bradley, J. Loader, G.L. Larsen, and E.W. Gelfand. 1997. Allergen-specific IgE and IL-5 are essential for the development of airways hyperresponsiveness. Am. J. Respir. Cell Mol. Biol. 16:674-682.

39. Lei, X.-F., Y. Ohlawara, M.R. Stampfli, C. Mastruzzo, R.A. Marr, D. Snider, Z. Xing, and M. Jordana. 1998. Disruption of antigen-induced inflammatory responses in CD40 ligand knock-out mice. J. Clin. Invest. 101:13421353.

40. Lamkhioued, B., P.M. Renzi, S. Abi-Younes, E.A. Garcia-Zepada, Z. Allakhverdi, O. Ghaffar, M.D. Rothenberg, A.D. Luster, and Q. Hamid. 1997. Increased expression of eotaxin in bronchoalveolar lavage and airways of asthmatics contributes to the chemotaxis of eosinophils to the site of inflammation. J. Immunol. 159:4593-4601.

41. Rothenberg, M.E., J.A. Maclean, E. Pearlman, A.D. Luster, and P. Leder. 1997. Targeted disruption of the chemokine eotaxin partially reduces antigen-induced tissue eosinophilia. J. Exp. Med. 185:785-790.

42. Maclean, J.A., R. Ownbey, and A.D. Luster. 1996. T cell-dependent regulation of eotaxin in antigen-induced pulmonary eosinophilia. J. Exp. Med. 184:1461-1469.

43. Rothenberg, M.E., R. Ownbey, P.D. Mehlhop, P.M. Loiselle, M. Van de Rijn, J.V. Bonvebtre, H.C. Oettgen, P. Leder, and A.D. Luster. 1996. Eotaxin triggers eosinophil-selective chemotaxis and calcium flux via a distinct receptor and induces pulmonary eosinophilia in the presence of interleukin-5 in mice. Mol. Med. 2:334-348.

44. Mould, A.W., K.I. Matthaei, I.G. Young, and P.S. Foster. 1997. Relationship between interleukin-5 and eotaxin in regulating blood and tissue eosinophilia in mice. J. Clin. Invest. 99:1064-1071.

45. Collins, P.D., S. Marleau, D.A. Griffiths-Johnson, P.J. Jose, and T.J. Williams. 1995. Cooperation between interleukin-5 and chemokine eotaxin to induce eosinophil accumulation in vivo. J. Exp. Med. 182:1169-1174. 